\title{
GLOSY
}

\author{
JAN SzULC
}

\section{GLOSA DO WYROKU NSA W WARSZAWIE Z DNIA 11 STYCZNIA 2012 R. II GSK 1365/10}

\section{TEZA:}

Badanie ciśnienia tętniczego w aptece wpisuje się w pojęcie ochrony zdrowia publicznego, o którym mowa w art. 86 u.p.f. Zarówno treść usługi farmaceutycznej, o której mowa w art. 2a ust. 1 pkt 7 ustawy o izbach aptekarskich, jak i treść ślubowania, o którym stanowi art. 4d ust. 3 tej ustawy wskazują, iż dokonywanie pomiaru ciśnienia w aptece wpisuje się w istotę samego zawodu farmaceuty, który wykonuje swoje obowiązki, mając zawsze na uwadze dobro pacjenta. Ze względu na fakt, iż dokonywanie pomiarów ciśnień na rzecz pacjentów nie zostało zastrzeżone dla innych podmiotów, nie można odbierać farmaceucie prawa dokonywania takich czynności, gdyż stałoby to w sprzeczności $\mathrm{z}$ istotą zawodu farmaceuty oraz $\mathrm{z}$ treścią pojęcia ochrony zdrowia publicznego, o którym mowa w art. 86 ust. 1 u.p.f.

«Lex» nr 1124037

\section{WSTĘP}

W wyroku z dnia 11 stycznia 2012 (sygn. akt II GSK 1365/10) Naczelny Sąd Administracyjny w Warszawie wypowiedział się co do możliwości świadczenia w aptece ogólnodostępnej usług innych niż 
wymienione w art. $86^{1}$ ustawy z dnia 6 września 2001 r. Prawo farmaceutyczne $^{2}$ (u.p.f.).

Przedmiotem oceny NSA była decyzja Wojewódzkiego Inspektora Farmacji (WIF) w B. nakazująca usunięcie ciśnieniomierza z lokalu apteki. W wyniku przeprowadzonego postępowania administracyjnego organ I instancji stwierdził brak podstaw do prowadzenia w aptekach ogólnodostępnych działalności polegającej na dokonywaniu pomiarów ciśnienia tętniczego krwi.

Skarżąca usunęła ciśnieniomierz z apteki, a następnie wniosła o uchylenie decyzji w całości na podstawie naruszenia art. $107 \S 1 \mathrm{kpa}$ oraz art. 86 ust. 1 w związku z ust. 2 u.p.f. Organ II instancji (Główny Inspektor Farmaceutyczny, GIF) utrzymał decyzję w mocy.

GIF stwierdził, że w aptece mogą być świadczone usługi inne niż wymienione w art. 86 ust. 2 u.p.f., ale w zakresie dopuszczonym przez obowiązujące przepisy. Zgodnie ze stanowiskiem GIF, w aptece można wykonywać dodatkowo wyłącznie usługi określone w art. 86 ust. 5 i 8 u.p.f.

1 Art. 86. 1. Apteka jest placówką ochrony zdrowia publicznego, w której osoby uprawnione świadczą w szczególności usługi farmaceutyczne, o których mowa w ust. 2.

2. Nazwa apteka zastrzeżona jest wyłącznie dla miejsca świadczenia usług farmaceutycznych obejmujących:

1) wydawanie produktów leczniczych i wyrobów medycznych, określonych w odrębnych przepisach;

2) sporządzanie leków recepturowych, w terminie nie dłuższym niż 48 godzin od złożenia recepty przez pacjenta, a w przypadku recepty na lek recepturowy zawierający środki odurzające lub oznaczonej ,wydać natychmiast” - w ciągu 4 godzin;

3) sporządzenie leków aptecznych;

4) udzielanie informacji o produktach leczniczych i wyrobach medycznych.

$[\ldots]$

8. W aptekach ogólnodostępnych na wydzielonych stoiskach można sprzedawać produkty określone w art. 72 ust. 5 posiadające wymagane prawem atesty lub zezwolenia, pod warunkiem, że ich przechowywanie i sprzedaż nie będą przeszkadzać podstawowej działalności apteki.

9. Minister właściwy do spraw zdrowia może określić, w drodze rozporządzenia, inne rodzaje działalności niż określone w ust. 2-4 i 8 związane z ochroną zdrowia dopuszczalne do prowadzenia $\mathrm{w}$ aptece.

2 Dz.U. z 2008 r. Nr 45, poz. 271, ze zm. 
Zdaniem GIF przepisy art. 2a ust. 1 pkt 7 ustawy z dnia 19 kwietnia 1991 o izbach aptekarskich ${ }^{3}$ (u.i.a.) oraz art. 4d ust. 1 i 3 u.i.a. nie mają zastosowania w sprawie, gdyż skarżąca nie wykazała związku pomiędzy dokonywaniem w aptece ogólnodostępnej pomiarów ciśnienia tętniczego krwi i decyzją o skorzystaniu przez farmaceutę z uprawnienia, o którym mowa w art. 96 ust. 2 u.p.f. ${ }^{4}$ lub skorzystania przez farmaceutę i technika farmaceutycznego z uprawnienia, o którym stanowi art. 96 ust. 4 u.p.f. ${ }^{5}$.

Strona wniosła następnie skargę do WSA, który podtrzymał stanowisko organów nadzoru. NSA z kolei stwierdził, że dokonano błędnej wykładni art. 86 ust. 1 u.p.f. poprzez ograniczenie zastosowania sformułowania „w szczególności” wyłącznie do usług określonych w ust. 5 i 8. NSA stwierdził również, że dokonano błędnej wykładni pojęć „ochrona zdrowia”, „osoba uprawniona” oraz że nie uwzględniono usług farmaceutycznych wymienionych w 2a ust. 1 pkt 7 u.i.a, a także, że został naruszony nakaz ograniczania swobody działalności gospodarczej w związku z art. 20 i 22 Konstytucji.

Wyrok NSA wymaga omówienia na trzech płaszczyznach:

1. zakresu usług dozwolonych do udzielania w aptece, tj. charakteru wyliczenia $\mathrm{z}$ art. 86 ust. 1, 2, 5 i 8 w związku z brakiem przepisów wykonawczych $\mathrm{z}$ art. 86 ust. 9 u.p.f.;

2. możliwości ograniczania swobody działalności gospodarczej w drodze aktu wykonawczego;

3. zakresu uprawnień kontrolnych Inspekcji Farmaceutycznej, bowiem Sąd w uzasadnieniu szeroko omówił jej kompetencje, stwierdzając m.in., że nie jest możliwe nakazanie usunięcia ciśnieniomierza z apteki.

3 Dz.U. Nr 41, poz. 179, ze zm.

4 W przypadku nagłego zagrożenia zdrowia lub życia farmaceuta, o którym mowa w art. 88 ust. 1, może wydać bez recepty lekarskiej produkt leczniczy zastrzeżony do wydawania na receptę w najmniejszym terapeutycznym opakowaniu, z wyłączeniem środków odurzających, substancji psychotropowych i prekursorów grupy I-R.

5 Farmaceuta i technik farmaceutyczny mogą odmówić wydania produktu leczniczego, jeżeli jego wydanie może zagrażać życiu lub zdrowiu pacjenta. 


\section{ZAKRES USŁUG DOZWOLONYCH W APTECE}

W związku z niejasnymi przepisami, utrwaloną przez lata praktyką były nierówności w możliwości świadczenia przez apteki dodatkowych usług ze względu na stopień liberalności w interpretowaniu przepisów przez właściwy miejscowo $\mathrm{WIF}^{6}$. Jest to sytuacja w oczywisty sposób niezgodna z przepisami konstytucyjnymi gwarantującymi praworządność działań administracji publicznej, równość obywateli oraz swobodę prowadzenia działalności gospodarczej, jednak brak jest woli u prawodawcy, by tą sytuację zmienić. Co więcej, sytuacja ta miała miejsce jeszcze przed uchwaleniem obecnie obowiązującej ustawy, w której również nie została przewidziana możliwość dokonywania pomiaru ciśnienia tętniczego $\mathrm{krwi}^{7}$. Wówczas NSA orzekł o niedopuszczalności świadczenia tego rodzaju usług w aptece ${ }^{8}$.

Przechodząc do kwestii wymienionej w punkcie pierwszym, oczywiste jest, że apteka przestała być wyłącznie miejscem sporządzania i realizowania leków. Jest to w ścisłym związku z koncepcją opieki farmaceutycznej, która ma uczynić z apteki swoiste centrum porad zdrowotnych. W związku z ogromnym rozwojem rynku leków dostępnych bez przepisu lekarza, to właśnie apteka jest często pierwszym miejscem, do którego trafia pacjent, farmaceuta powinien objąć go opieką i udzielić kompleksowej porady ${ }^{9}$.

NSA, dopuszczając możliwość mierzenia ciśnienia tętniczego w aptece, odwołał się do treści art. 86 u.p.f. określającego aptekę jako ,placówkę ochrony zdrowia publicznego". Z tego też faktu sąd wywiódł,

6 M. Kormeba, [w:] M. Kondrat, Prawo farmaceutyczne. Komentarz, Warszawa 2009, s. 816.

7 Ustawa z dnia 10 października 1991 r. o środkach farmaceutycznych, materiałach medycznych, aptekach, hurtowniach i Inspekcji Farmaceutycznej; Dz.U. Nr 105, poz. 452, ze zm.

8 P. Bujakiewicz, Czy $w$ aptece można wykonywać dodatkowe czynności np. mierzenie ciśnienia krwi pacjentowi, Pomorsko-Kujawska Izba Aptekarska, http:// www.bydgoszcz.oia.org.pl/dat/files/126_Czy_w_aptece_mozna_wykonywac_dodatkowe_czynnosci_np.doc.

9 Rezolucja Rady Europy ResAP (2001) 2 przyjęta przez Komitet Ministrów dnia 21 marca 2001 o roli aptekarza w zakresie bezpieczeństwa zdrowia. 
że w aptekach dozwolone jest świadczenie usługi mierzenia ciśnienia tętniczego krwi, gdyż jest to ściśle związane z prawem do ochrony zdrowia zagwarantowanym przez art. 68 Konstytucji.

Jak trafnie zwraca uwagę M. Koremba, pojęcie placówka ochrony zdrowia publicznego ,nie zostało bliżej sprecyzowane w przepisach. Na pewno nie należy utożsamiać go z pojęciem «zakładu opieki zdrowotnej» regulowanym odrębnymi przepisami (ustawy o zakładach opieki zdrowotnej [w aktualnym stanie prawnym obowiązuje ustawa z dnia 15 kwietnia o działalności leczniczej (Dz. U. z 2013 r. poz. 217), dalej „u.d.1.- przyp. aut.])" "10. W u.d.1. zdefiniowano „działalność leczniczą" jako świadczenie usług zdrowotnych (art. 3 ust. 1), a ponadto promocję zdrowia oraz realizację zadań dydaktycznych i badawczych w powiązaniu z udzielaniem świadczeń zdrowotnych i promocją zdrowia, w tym wdrażaniem nowych technologii medycznych oraz metod leczenia (art. 3 ust. 2). Świadczenie zdrowotne natomiast to działania służące zachowaniu, ratowaniu, przywracaniu lub poprawie zdrowia oraz inne działania medyczne wynikające z procesu leczenia lub przepisów odrębnych regulujących zasady ich wykonywania (art. 2 ust. 1 pkt 10 u.d.1.), natomiast podmioty wykonujące działalność leczniczą zostały wymienione w art. 4 u.d.1., brak wśród nich aptek.

Wielowiekową tradycją jest rozdzielenie funkcji leczenia od sporządzania leków. Jest to uzasadnianie m.in. koniecznością wzajemnej kontroli lekarza i aptekarza. Ustawodawca również wyraźnie rozgraniczył działalność leczniczą od świadczenia usług farmaceutycznych, określając aptekę jako „placówkę ochrony zdrowia publicznego”. Zgodnie z zasadą zakazu wykładni synonimicznej różnym pojęciom nie można nadawać tożsamych znaczeń ${ }^{11}$.

Podsumowując powyższe rozważania, bez wątpienia nie można utożsamiać apteki z podmiotem wykonującym działalność leczniczą, skoro po pierwsze nie została tak scharakteryzowana w u.d.l., a po drugie w u.p.f. została określona jako ,placówka zdrowia publiczne-

10 M. KormebA, op. cit., s. 812.

11 L. Morawski, Wykładnia $w$ orzecznictwie sąów. Komentarz, Torun 2002, s. 144-145. 
go”. Z tego też względu samo zdefiniowanie apteki jako „placówki ochrony zdrowia publicznego" nie jest równoznaczne, w omawianym przypadku, z umożliwieniem dokonywania pomiarów ciśnienia tętniczego w aptekach.

\section{OPIEKA FARMACEUTYCZNA}

NSA przytoczył czynności wchodzące w wykonywanie zawodu farmaceuty. Zgodnie $\mathrm{z}$ art. 2a ust. 1 pkt 6 i 7 u.i.a. wykonywanie zawodu farmaceuty ma na celu ochronę zdrowia publicznego i obejmuje udzielanie usług farmaceutycznych polegających w szczególności na udzielaniu informacji i porad dotyczących działania i stosowania produktów leczniczych i wyrobów medycznych oraz sprawowaniu opieki farmaceutycznej polegającej na dokumentowanym procesie, w którym farmaceuta, współpracując $\mathrm{z}$ pacjentem i lekarzem, a w razie potrzeby z przedstawicielami innych zawodów medycznych, czuwa nad prawidłowym przebiegiem farmakoterapii w celu uzyskania określonych jej efektów poprawiających jakość życia pacjenta. Wymienia się również sporządzanie i wytwarzanie produktów leczniczych, wydawanie ich z apteki oraz sporządzanie leków recepturowych i aptecznych. Jak widać, przepisy ustawy u.i.a. pozostają w ścisłym związku z art. 86 u.p.f. W obu przepisach użyto sformułowania „usługi farmaceutyczne”, w związku z tym niemożliwym jest traktowanie katalogu usług farmaceutycznych wymienionych w art. 86 u.p.f. jako katalogu zamkniętego (lege non distinguente nec nostrum est distinguere).

Konieczne jest jednak rozważanie, czy samodzielne mierzenie ciśnienia przez pacjenta spełnia przesłanki opieki farmaceutycznej. Sama koncepcja została opracowana w 1975 r. ${ }^{12}$, jednak opieka farmaceutyczna nie została dotychczas w Polsce wdrożona, chociaż nowelą u.i,a. z 2008 r. ${ }^{13}$ stworzono częściowo prawne podstawy jej funkcjonowania. Opiekę farmaceutyczną najczęściej definiuje się

12 A. Zimmermann, Apteka jako ośrodek świadczący opiekę farmaceutyczna, Warszawa 2010, s. 174.

13 Brzmienie art. 2a zmienione art. 1 pkt 2 ustawy z dnia 10 stycznia 2008 r. o zmianie ustawy o izbach aptekarskich (Dz.U. Nr 47, poz. 273). 
za Ch. Heplerem i L. Strandem jako ,proces, w którym farmaceuta - współpracując z pacjentem i lekarzem oraz innymi zawodami medycznymi - czuwa nad prawidłowym przebiegiem farmakoterapii w celu uzyskania określonych efektów poprawiających jakość życia pacjenta"14. Opieką farmaceutyczną są zinstytucjonalizowane zadania aptekarza wobec pacjenta, poszerzone o nowe elementy. Farmaceuta, realizujący opiekę farmaceutyczna, staje się współodpowiedzialny za proces leczenia pacjenta ${ }^{15}$.

Kluczową kwestią w sprawowaniu opieki farmaceutycznej jest, by była ona realizowana wraz z dokumentowaniem procesu leczenia pacjenta przy ścisłej współpracy z lekarzami i pielęgniarkami. Czyli ten proces musi być ciągły, a farmaceuta zobligowany jest do sprawowania kontroli nad zmianami stanu zdrowia każdego z pacjentów.

Należy zwrócić uwagę, że apteka w toku opieki farmaceutycznej zbiera dane wrażliwe. Jest to jedna z przeszkód do wprowadzenia w pełnym zakresie opieki farmaceutycznej w Polsce, gdyż dane wrażliwe podlegają szczególnej ochronie, przepisy prawa szczegółowo regulują podmioty uprawnione do ich gromadzenia, a także sposób magazynowania ${ }^{16}$. Skarżąca w żaden sposób nie dowiodła, że gromadzi wyniki mierzenia ciśnienia tętniczego krwi przez pacjentów oraz że dostosowuje na podstawie tych wyników proces leczenia, a w szczególności, że współpracuje w tym zakresie z lekarzami ordynującymi leki poszczególnym pacjentom. Trudno więc przyjąć, by mierzenie ciśnienia tętniczego $\mathrm{w}$ tym wypadku było faktycznie realizowaniem opieki farmaceutycznej, rozumianej w sposób określony powyżej.

A. Skowron wymienia szereg warunków, które muszą zostać spełnione $\mathrm{w}$ aptece, by mogła ona stać się miejscem świadczenia opieki farmaceutycznej:

14 Podaję za A. Skowron, Wytyczne opieki farmaceutycznej w Polsce, «Farmacja Polska»13/2006, s. 579.

15 W. Stożkowska, Opieka farmaceutyczna- wyzwanie, konieczność i szansa, «Farmacja Polska» 5/2005, s. 211.

16 Ustawa z dnia 29 sierpnia 1997 r. o ochronie danych osobowych (Dz.U. z 2002 r. Nr 101, poz. 926 ze zm.); A. SKOWRON, Model opieki farmaceutycznej dla polskiego systemu zdrowotnego, Wydawnictwo Fall, Kraków 2011, s. 42. 
1. zatrudniony farmaceuta posiadający odpowiednie kwalifikacje do prowadzenia opieki farmaceutycznej,

2. ustalenie podziału obowiązków i przygotowanie personelu pomocniczego (technicy farmaceutycznej) do pomocy przy czynnościach administracyjnych,

3. przygotowanie wydzielonego miejsca do pracy z pacjentem,

4. ustalenie rodzaju i wielkości populacji docelowej pacjentów, którzy objęci mają zostać opieką farmaceutyczną,

5. przygotowanie i przeprowadzenie wśród pacjentów akcji informacyjnej dotyczącej opieki farmaceutycznej ${ }^{17}$.

Z wymogu świadczenia opieki farmaceutycznej w wydzielonym pomieszczeniu wynika, że w polskim stanie prawnym nie jest możliwe prowadzenie opieki farmaceutycznej. Przepisy prawa jasno stanowią o wymaganiach, jakie musi spełniać lokal apteki ${ }^{18}$. Zgodnie $\mathrm{z}$ rozporządzeniem w skład powierzchni podstawowej lokalu apteki wchodzą (§ 1) m.in.: izba ekspedycyjna, izba recepturowa, zmywalnia, magazyn lub magazyny produktów leczniczych, magazyn lub magazyny do przechowywania asortymentu wymienionego w art. 72 ust. 5 u.p.f. ${ }^{19}$, jeżeli jest on prowadzony przez aptekę, pomieszczenie administracyjno-szkoleniowe, komora przyjęć, usytuowana w pobliżu wejścia do apteki przeznaczonego dla dostaw towaru i dla personelu, archiwum. W skład powierzchni pomocniczej lokalu apteki natomiast (§ 3): pomieszczenie socjalne, szatnia dla personelu, pomieszczenie sanitarne, pomieszczenie przeznaczone do przechowywania sprzętu porządkowego i środków służących do utrzymania czystości, powierzchnia komunikacyjna (korytarze, przedsionki itp.). Jest więc jasne, że przepisy prawne nie dopuszczają przeznaczenia żadnego z pomieszczeń apteki na prowadzenie opieki farmaceutycznej, a jedynym pomieszczeniem do którego dostęp ma pacjent, jest izba ekspedycyjna, czyli miejsce

17 A. Skowron, Model opieki farmaceutycznej..., s. 44-45.

18 Rozporządzenie Ministra Zdrowia z dnia 26 września 2002 r. w sprawie wykazu pomieszczeń wchodzących w skład powierzchni podstawowej i pomocniczej apteki; Dz.U. Nr 161, poz. 1338 oraz z 2005 r. Nr 92, poz. 882.

19 M.in. wyroby medyczne, suplementy diety, kosmetyki (z wyłączeniem kosmetyków przeznaczonych do perfumowania lub upiększania), środki dezynfekujące. 
wydawania produktów leczniczych i innych produktów dopuszczonych do obrotu w aptece. Co więcej, izba ekspedycyjna apteki nie może stanowić pomieszczenia przechodniego ${ }^{20}$, tzn. nie może być z niej dostępu do innych pomieszczeń. Wskazuje to na intencję prawodawcy do odseparowania pacjentów od pozostałych pomieszczeń apteki, co jest wzmocnione także wymogiem stworzenia osobnego wejścia do lokalu apteki dla jej personelu ${ }^{21}$.

Uwzględniając wszystko powyższe, należy odrzucić twierdzenie, by umożliwienie pacjentom korzystania z urządzenia do mierzenia ciśnienia tętniczego krwi spełniało przesłanki świadczenia usługi farmaceutycznej w rodzaju opieki farmaceutycznej. Opieką farmaceutyczną jest skoordynowany proces opierający się na współpracy pomiędzy pacjentem, farmaceutą i lekarzem, w którym konkretny farmaceuta otacza opieką konkretnego pacjenta i ustawicznie uczestniczy w procesie leczenia.

Należy przy tym zwrócić uwagę na podstawowy błąd w interpretacji art. 86 ust. 1 u.p.f. przez NSA. Otóż w przepisie tym występuje sformułowanie „osoba uprawniona”, nie zaś farmaceuta. Sąd natomiast całkowicie pomija to rozróżnienie, utożsamiając „osobę uprawnioną” z farmaceutą. Co więcej, Sąd jest niekonsekwentny i rozciąga uprawnienia farmaceutów $z$ art. 2a u.i.a. na techników farmacji, co jest oczywiście nieprawidłowe.

W związku z tym, wykładnia art. 86 ust. 1 u.p.f. powinna być dokonywana w związku z art. 90 u.p.f. ${ }^{22}$.Uprawnienia technika farmaceutycznego są mocno ograniczone w stosunku do farmaceuty. Jest on pracownikiem niesamodzielnym, gdyż może wykonywać czynności wyłącznie pod nadzorem kierownika apteki lub wyznaczonego na czas jego nieobecności farmaceuty (art. 88 ust. 4 u.p.f.).

20 § 3 ust. 2 rozporządzenia Ministra Zdrowia z dnia 30 września 2002 r. w sprawie szczegółowych wymogów, jakim powinien odpowiadać lokal apteki (Dz.U. Nr 171, poz. 1395 oraz z 2005 r. Nr 92, poz. 882).

$21 \S 5$ ust 1 pkt 2 ww. rozporządzenia.

22 Przy wykonywaniu w aptece czynności fachowych mogą być zatrudnieni wyłącznie farmaceuci i technicy farmaceutyczni w granicach ich uprawnień zawodowych. 
Przyjęcie rozumowania NSA prowadziłoby do sytuacji, w której z tego samego przepisu można wysunąć dwa całkowicie odmienne wnioski. Otóż, z jednej strony, mierzenie ciśnienia tętniczego krwi byłoby przez pacjentów dopuszczalne $z$ uwagi na uprawnienia farmaceuty, ale, $\mathrm{z}$ drugiej strony, byłoby zakazane ze względu na uprawnienia technika farmacji. Z tego względu należy przychylić się do poglądów doktryny, nakazujących stosowanie wąskiej interpretacji „usług farmaceutycznych" z art. 86 ust. 1 u.p.f., tj. ściśle w związku z art. 86 ust. 2 i 8 u.p.f.

Co więcej, nie można zgodzić się z twierdzeniem NSA, że art. 86 u.p.f. stanowi lukę prawną. Zgodnie z ugruntowanym poglądem orzecznictwa „luką w prawie jest taki brak regulacji, co do którego można racjonalnie twierdzić, że nie jest przez ustawodawcę zamierzony. Ponadto nie może być mowy o tzw. lukach pozornych oraz lukach w tym sensie, że ktoś uważa, iż dane materie powinny być prawnie uregulowane, a nie są, co należałoby potraktować jedynie jako niezgodności czyjegoś ideału prawnego z prawem obowiązującym. Ocena, czy mamy do czynienia jedynie z kwestią prawnie obojętną, czy z luką w prawie powinna być ściśle związana ze znajomością prawa pozytywnego oraz preferencjami aksjologicznymi i zamierzonymi celami, jakie postawił sobie ustawodawca. Dopiero na podstawie tych dwóch przesłanek można określić, czy dany stan rzeczy prawodawca świadomie pozostawił poza zakresem regulacji prawnej, czy też dopuścił do powstania luki w prawie" ${ }^{23}$.

Stworzenie zamkniętego katalogu usług farmaceutycznych dopuszczonych do świadczenia $\mathrm{w}$ aptece oraz umożliwienie ministrowi właściwemu do spraw zdrowia określenia innych usług w akcie wykonawczym jasno wskazuje, że w omawianym przypadku brak jest podstaw do postawienia tezy o luce w prawie w art. 86 u.p.f.

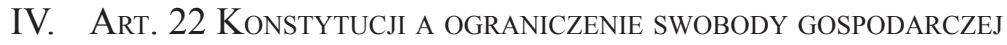
AKTEM WYKONAWCZYM

W omawianym orzeczeniu NSA orzekł, że brak skorzystania przez ministra właściwego do spraw zdrowia z delegacji ustawowej

23 Postanowienie Sądu Najwyższego z dnia 25 maja 2001 r. WA 15/01. 
do wydania rozporządzenia określającego inne rodzaje działalności niż wymienione $\mathrm{w}$ u.p.f. związane $\mathrm{z}$ ochroną zdrowia dopuszczalne do prowadzenia w aptece (art. 86 ust. 9 u.p.f.) nie stanowi zakazu świadczenia innych rodzajów działalności niż wymienione w ustawie. Zdaniem NSA z art. 22 Konstytucji wynika, że wszelkie ograniczenia swobody działalności gospodarczej „muszą być wyraźnie ustanowione w ustawie". Zdaniem sądu użycie przez ustawodawcę sformułowania „W szczególności”, wskazuje, że w aptece dopuszczalne jest świadczenie innych usług, niż wymienione w art. 86 ust 2 i 5 u.p.f., a brak rozporządzenia z art. 86 ust. 9 u.p.f. nie może przesądzać o niedopuszczalności świadczenia innych usług.

Art. 22 Konstytucji zezwala, by ograniczanie swobody działalności gospodarczej dokonywane było wyłącznie „w drodze ustawy” i tylko „ze względu na ważny interes publiczny”. Zgodnie z art. 87 Konstytucji źródłami prawa powszechnie obowiązującego w Polsce są Konstytucja, ustawy, ratyfikowane umowy międzynarodowe oraz rozporządzenia. Konstytucja również w art. 92 określa, że rozporządzenia są wydawane przez organy wskazane w Konstytucji na podstawie szczegółowego upoważnienia zawartego w ustawie i w celu jej wykonania. Należy w związku z tym rozważyć, czy rzeczywiście wyliczenie usług i czynności dopuszczalnych $\mathrm{w}$ aptece $\mathrm{w}$ rozporządzeniu, wydanym na podstawie art. 86 ust. 9 u.p.f., byłoby rzeczywiście nieskuteczne w kontekście art. 22 Konstytucji.

W obecnym stanie konstytucyjnym ustawodawca bardzo rygorystycznie określił zarówno katalog aktów prawnych powszechnie obowiązujących, jak i związek rozporządzenia z ustawą upoważniającą: „Pomiędzy tą ustawą a rozporządzeniem powinien istnieć merytoryczny związek i normy rozporządzenia powinny służyć realizacji ustawy. Treść regulacji zawartych w rozporządzeniu musi dotyczyć tej samej problematyki, zmierzać do realizacji tych samych zadań i służyć tym samym celom, jakie znajdują wyraz w przepisach ustawy. Stąd też rozporządzenie, mając na celu wykonanie ustawy, musi uwzględniać określony w zawartym $\mathrm{w}$ niej upoważnieniu zakres spraw przekazanych mu do uregulowania. Wykorzystanie choćby wyraźnych upoważnień ustawowych do innych celów, niż założone w upoważnieniu, albo 
wyjście poza jego zakres stanowi naruszenie legalności działania RM lub ministrów. Nie można przy tym zapominać, że dopuszczalność istnienia rozporządzenia regulującego materie ustawowe rodzi ważne problemy z punktu widzenia funkcjonowania podziału władz. Z tego względu nie może dojść do tego, aby RM lub ministrowie otrzymali generalne pełnomocnictwo do wydawania takich aktów o charakterze abstrakcyjnym i generalnym, gdyż mogliby de facto zastąpić suwerena lub jego przedstawicieli w działalności prawodawczej"24.

Szczegółowo kwestia wydawania rozporządzeń została uregulowana w Zasadach techniki prawodawczej ${ }^{25}$ (z.t.p.). Przede wszystkim warto przywołać $\S 115$ z.t.p., zgodnie z którym w rozporządzeniu zamieszcza się tylko przepisy regulujące sprawy przekazane do unormowania w przepisie upoważniającym (upoważnieniu ustawowym). Niezwykle istotny w kontekście prowadzonych w niniejszej pracy rozważań jest również $§ 116$ z.t.p. zabraniający zamieszczania w rozporządzeniu postanowień niezgodnych z ustawą upoważniającą.

W doktrynie dostrzega się, że rozporządzenie jako akt wydany „w celu wykonania ustawy" zawiera w sobie obowiązek realizowania takiego samego celu, jaki został założony w ustawie. Cel rozporządzenia jest ściśle związany z ustawą i nie może być określany w oderwaniu od celu ustawy. „Związek ten wyraża się m.in. przez założenie, że ustawa wraz z aktem wykonawczym tworzą całość zaprogramowaną przez ustawę i kompleksowo regulują pewien zakres stosunków społecznych"26. Rozporządzenia mają uszczegółowiać i precyzować ogólne zasady określone w akcie rangi ustawowej. Rozporządzenie może być również niekiedy warunkiem wejścia w życie ustawy, stworzenia prawnych ram jej funkcjonowania i zrealizowania zamierzonych

24 B. BanaszaK, Konstytucja Rzeczypospolitej Polskiej. Komentarz, Warszawa 2009, s. 465.

25 Rozporządzenie Prezesa Rady Ministrów z dnia 20 czerwca 2002 r. w sprawie „Zasad techniki prawodawczej”; Dz.U. Nr 100, poz. 908.

26 B. SKWARA, Rozporzadzenie jako akt wykonawczy do ustawy w polskim prawie konstytucyjnym, Warszawa 2010, s. 157-158. 
w niej celów, rozporządzenie może również odciążać parlament od kwestii zbyt drobiazgowych, o nazbyt technicznym charakterze ${ }^{27}$.

M. Szydło podkreśla z kolei ${ }^{28}$, że sformułowanie ,tylko w drodze ustawy” $z$ art. 22 Konstytucji nie jest tożsame ze sformułowaniem ,tylko w ustawie" z art. 33 Konstytucji. Zdaniem M. Szydło ograniczenie działalności gospodarczej tylko w drodze ustawowej nie ogranicza możliwości delegowania bardziej szczegółowego regulowania materii w rozporządzeniach. Gdyby zamysłem ustawodawcy było zawężenie możliwości ograniczania swobody działalności gospodarczej wyłącznie do ustaw, to powinien, analogicznie do art. 33 Konstytucji, użyć sformułowania ,tylko w ustawie”, przez co wszelkie ograniczenia w drodze rozporządzeń byłyby niekonstytucyjne. Dalej M. Szydło dowodzi, że ograniczenie wolności działalności gospodarczej może również nastąpić w rozporządzeniu, lecz jedynie w sytuacji, gdy spełnia ono wymogi z art. 92 Konstytucji i zostało wydane na podstawie szczegółowego upoważnienia zawartego w ustawie w celu jej wykonania ${ }^{29}$.

Podobny przypadek rozstrzygną Trybunał Konstytucyjny w wyroku z dnia 25 lipca 2006 r. (sygn. akt P 24/05), w którym Trybunał badał dopuszczalność ograniczenia swobody działalności gospodarczej w rozporządzeniu wydanym na podstawie ustawy z dnia 10 kwietnia 1997 r. - Prawo energetyczne. W uzasadnieniu do wyroku Trybunał stwierdza: „Wydaje się, że w odniesieniu do ograniczania wolności działalności gospodarczej wymóg zamieszczenia całości regulacji «tylko w ustawie», bez możliwości zamieszczenia w ustawie upoważnień do wydania aktów wykonawczych, byłby nadmierny. Skoro wolność działalności gospodarczej może - w świetle dotychczasowego orzecznictwa Trybunału Konstytucyjnego - podlegać większym ograniczeniom niż prawa i wolności o charakterze osobistym bądź politycznym, przemawia to również za dopuszczeniem regulacji granic wolności gospodarczej w rozporządzeniach wydanych na podstawie upoważnienia ustawowego".

27 Tamże, s. 161-162.

28 M. SzYdŁo, Wolność działalności gospodarczej jako prawo podstawowe, Bydgoszcz-Wrocław, s. 105.

29 Tamże, s. 127. 
Wpisanie do ustawy rozwiązania, zgodnie z którym w rozporządzeniu zostaną określone usługi dozwolone do świadczenia w aptece, jest co do zasady zgodne $\mathrm{z}$ Konstytucją oraz rolą rozporządzenia jako aktu wykonawczego. To ustawą wprowadzono szereg ograniczeń w swobodzie działalności gospodarczej w odniesieniu do aptek, natomiast rozporządzenie ma charakter w tym wypadku ściśle techniczny. Jak zostało stwierdzone wyżej, rozporządzenie wręcz ma poszerzać zakres swobody wobec generalnego zakazu ustawowego. Wbrew bowiem stanowisku NSA, użycie w art. 86 ust. 1 u.p.f. sformułowania „w szczególności”, nie skutkuje przyzwoleniem ustawodawcy na świadczenie dowolnych usług na terenie aptek.

Należy przy tym zaznaczyć, ze w art. 86 ust. 1 u.p.f. sformułowanie „W szczególności” zostało użyte w sposób nieprawidłowy. Z.t.p. jasno stanowią, że „w szczególności” używane jest w wyliczeniach zakresowych, w których ma mieć ono charakter wyłącznie przykładowy (§ 153 ust. 3 z.t.p.). W art. 86 ust. 1 u.p.f. takiego wyliczenia brak. Natomiast wyliczenie w art. 86 ust. 2 u.p.f. bez wątpienia ma charakter enumeratywny.

Zgodnie z zasadami techniki prawodawczej każdą samodzielną myśl ujmuje się w odrębny artykuł (§ 55 ust. 1 z.t.p), natomiast jeżeli samodzielną myśl wyraża zespół zdań, dokonuje się podziału artykułu na ustępy. Z uwagi, że artykuł powinien być jednozdaniowy ( 55 ust. 2 z.t.p., w przypadku, gdy daną myśl wyraża zespół zdań, dzieli się go na ustępy (§ 55 ust. 3 z.t.p.). Podział na ustępy stosuje się również, jeżeli między zdaniami wyrażającymi samodzielne myśli występują powiązania treściowe, ale treść żadnego z nich nie jest na tyle istotna, aby wydzielić ją w odrębny artykuł ( $\$ 55$ ust. 4 z.t.p.). Wynika z tego, że co do zasady dany artykuł powinien być traktowany jako samodzielna całośćc 30 .

W opinii autora ust. 1 art. 86 u.p.f. stanowi przepis ogólny, jest to legalna definicja apteki, natomiast kolejne ustępy stanowią jego doprecyzowanie. Czyli w omawianym przypadku to właśnie w kolejnych

30 Tak też G. WIERCZYŃSKI, Komentarz do zat. $\S 55$ rozporządzenia $w$ sprawie „Zasad techniki prawodawczej” [w:] Redagowanie i ogłaszanie aktów prawnych. Komentarz, Warszawa 2009, «Lex» nr 55436. 
ustępach art. 86 u.p.f. odnajdujemy doprecyzowanie sformułowania „w szczególności”. Art. 86 ust. 2 u.p.f. zawiera enumeratywne wyliczenie usług farmaceutycznych świadczonych w aptece, które są rozszerzone w art. 86 ust. 3 u.p.f. dla aptek szpitalnych. Kluczowa w tym wypadku wydaje się być redakcja art. 86 ust. 4 u.p.f. o treści: „W aptekach szpitalnych poza udzielaniem usług farmaceutycznych: 1) prowadzona jest ewidencja badanych produktów leczniczych oraz produktów leczniczych i wyrobów medycznych otrzymywanych w formie darowizny; 2) ustalane są procedury wydawania produktów leczniczych lub wyrobów medycznych przez aptekę szpitalną na oddziały oraz dla pacjenta". Z kolei art. 86 ust. 8 u.p.f. daje możliwość wprowadzenia w aptekach ogólnodostępnych na wydzielonych stoiskach sprzedaży produktów określonych w art. 72 ust. 5 u.p.f., posiadających wymagane prawem atesty lub zezwolenia, pod warunkiem, że ich przechowywanie i sprzedaż nie będą przeszkadzać podstawowej działalności apteki.

Dwa wymienione ustępy to jedyne wyjątki od wyliczonych wcześniej usług farmaceutycznych świadczonych w aptece. W doktrynie przyjmuje się ponadto, że ustępy powinny być formułowane w kolejności „od ogółu do szczegółu” "31, w omawianym przypadku oznacza to, że ostateczne doprecyzowanie odstępstw od generalnego zakazu $\mathrm{z}$ art. 86 ust. 1 i 2 u.p.f. nastąpi w rozporządzeniu wydanym przez ministra właściwego do spraw zdrowia. W wyroku WSA w Warszawie z dnia 17 października 2008 r. (sygn. akt VII SA/Wa 698/08) stwierdził „Zawarty w definicji apteki zapis «w szczególności» należy bowiem odczytywać z uwzględnieniem treści ust. 9 art. 89 [mowa oczywiście o art. 86 - przypis autora] ww. ustawy, zgodnie z którym tylko minister właściwy do spraw zdrowia może określić, w drodze rozporządzenia, inne rodzaje działalności niż określone w ust. 2-4 i 8 związane z ochroną zdrowia dopuszczalne do prowadzenia w aptece”.

W związku z tym nie można zgodzić się z poglądem sądu, że rozporządzenie ministra właściwego do spraw zdrowia byłoby sprzeczne z zasadą swobody działalności gospodarczej. Ustawa formułuje za-

31 G. WIERCZYŃSKI, Komentarz do $\S 55$ rozporządzenia... 
sadniczy zakaz podejmowania jakichkolwiek innych czynności w aptece poza wymienionymi w ustawie, dając równocześnie ministrowi właściwemu do spraw zdrowia możliwość - wydanie rozporządzenia jest bowiem fakultatywne - rozszerzenia tego katalogu w drodze przepisów wykonawczych.

Podobnie orzekł Trybunał Konstytucyjny w cytowanym wyżej wyroku: „Sformułowanie „w drodze ustawy” (art. 22) wskazuje, że do ograniczenia wolności może dojść przy wykorzystaniu ustawy, bez której konstruowanie ograniczenia w ogóle nie może mieć miejsca. Oznacza to, że ustawa może także jedynie legitymować ograniczenie wprowadzone w rozporządzeniu wydanym na jej podstawie. Sformułowanie ,tylko w ustawie” (art. 31 ust. 3) wskazuje natomiast na wolę ustrojodawcy, aby kompletny zakres (kontur) ograniczenia wolności lub prawa był określony bezpośrednio w ustawie". Wobec takiego stanowiska TK jest oczywiste, że rozporządzenie z art. 86 ust. 9 u.p.f. w żaden sposób nie naruszałoby art. 22 Konstytucji.

\section{ZAKRES KONTROLI INSPEKCJI FARMACEUTYCZNEJ}

W końcowej część uzasadnienia NSA stwierdził, że art. 120 ust. 1 pkt 2 u.p.f. ${ }^{32}$ nie jest podstawą do wydania przez inspekcję farmaceutyczną decyzji nakazującej usuniecie ciśnieniomierza z lokalu apteki. NSA dowodzi, że skoro w aptece nie zostały naruszone wymagania dotyczące obrotu produktami leczniczymi oraz wyrobami medycznymi, przepisu art. 120 u.p.f. nie można zastosować do wydania decyzji o usunięciu ciśnieniomierza z lokalu apteki. Powołuje się przy tym na art. 7 Konstytucji ${ }^{33}$ oraz zasady ogólnej z art. $6 \mathrm{kpa}^{34}$.

Oczywiste jest, że w żadnym z przepisów u.p.f. nie została sformułowana kompetencja do usuwania ciśnieniomierza, skoro nie została przewidziana możliwość jego umieszczenia w lokalu apteki. Jednak

32 W razie stwierdzenia naruszenia wymagań dotyczących obrotu produktami leczniczymi lub wyrobami medycznymi właściwy organ nakazuje, w drodze decyzji, usunięcie w ustalonym terminie stwierdzonych uchybień.

33 Organy władzy publicznej działają na podstawie i w granicach prawa.

34 Organy władzy publicznej działają na podstawie prawa. 
Inspekcja Farmaceutyczna posiada kompetencję do całościowego monitorowania obrotu produktami leczniczymi na wszystkich szczeblach dystrybucji. W związku z rygorystycznymi normami wybrane uregulowania dotyczące aptek zostały uregulowane powyżej, inspekcja farmaceutyczna kontroluje całokształt działalności prowadzonej przez apteki.

Art. 109 pkt 4 u.p.f. przyznaje Inspekcji Farmaceutycznej prawo do kontrolowania aptek. I to z tego uprawnienia należy wywodzić kompetencje do weryfikacji całości działalności apteki, tj. prowadzenia apteki zgodnie $\mathrm{z}$ wymogami określonymi w zezwoleniu na prowadzenie apteki. W art. 100 ust. 2 pkt 3 u.p.f. ustanowiono wymóg dołączenia do wniosku o wydanie zezwolenia na prowadzenie apteki planu i opisu technicznego pomieszczeń przeznaczonych na aptekę. Umieszczenie ciśnieniomierza może znacząco utrudniać realizację podstawowego zadania apteki, czyli świadczenia usług farmaceutycznych wymienionych w art. 86 ust. 2 u.p.f. Można się przy tym wesprzeć art. 86 ust. 8 u.p.f., który precyzuje, że prowadzenie sprzedaży innych produktów jest uzależnione od możliwości organizacyjnych apteki, tj. nie może to zakłócać jej podstawowej działalnościci ${ }^{35}$.

W działalności organów administracyjnym i orzecznictwie sądów administracyjnych znaleźć można liczne przypadki, w których inspekcja farmaceutyczna zabraniała prowadzenia $\mathrm{w}$ aptece działalności, które nie zostały wymienione w u.p.f.. M. Ożóg przytacza następujące przykłady, w których aptekom odmówiono: 1) prawa do udostępniania lokalu apteki dla celów przeprowadzenia badań densytometrycznych oraz udzielania porad i wypisywania recept przez lekarzy specjalistów, 2) prowadzenia zapisów pacjentów na badania i konsultacje lekarskie (które to badania i konsultacje odbywały się już poza lokalem apteki), 3) eksponowania w aptece nagród możliwych do otrzymania w ramach programu lojalnościowego i prowadzenia takiego programu w ogóle, 4) pomiaru ciśnienia tętniczego krwi, 5) mierzenia poziomu cukru we krwi, 6) prowadzenia badań profilaktycznych w kierunku

35 Por. wyrok Naczelnego Sądu Administracyjnego z dnia 20 listopada 2008, sygn. akt II GSK 511/08. 
wykrywania osteoporozy w przystosowanym do tego samochodzie, ustawionym w pobliżu apteki i korzystającym z jej zasobów (energii elektrycznej) ${ }^{36}$.

W prawie administracyjnym zakazane jest stosowanie wykładni $\mathrm{z}$ analogii $\mathrm{w}$ odniesieniu do kompetencji organów administracji ${ }^{37}$. Jednak tak wąskie pojmowanie uprawnień Inspekcji Farmaceutycznej, jak to przyjął NSA, stanowi niebezpieczny precedens. Powstałaby niezamierzona przez ustawodawcę luka w prawie, tj. Inspekcja Farmaceutyczna zostałaby pozbawiona możliwości wpływu na detaliczny obrót produktem leczniczym, a także na zatarcie rozróżnienia na apteki $\mathrm{i}$ inne placówki handlowe. Byłoby to zdecydowanie niekorzystne dla bezpieczeństwa życia i zdrowia ludności. W związku z tym, przy zastosowaniu analogia legis można wywnioskować uprawnienie inspekcji farmaceutycznej do zabronienia prowadzenia w aptece określonej działalności, analogicznie do art. 86 ust. 8 u.p.f., czyli w sytuacji, w której powodowałaby to utrudnienie bądź uniemożliwienie realizowania w aptece podstawowych usług farmaceutycznych. Wykładnia przepisów prowadząca do powstania luki jest zabroniona ${ }^{38}$, a efektem byłoby, że znacząca część działalności apteki znalazłaby się poza kontrolą organów administracji.

Nawet jednak odrzucając możliwość stosowania w tym konkretnym przypadku analogii, można przyjąć, że Inspekcja Farmaceutyczna przeprowadzała kontrolę prowadzenia przez aptekę działalności zgodnie z zezwoleniem. Jako że świadczenie przez aptekę usługi mierzenia ciśnienia tętniczego nie jest objęte zezwoleniem, narusza warunki prowadzenia apteki. Z uwagi, że wiodącą funkcją apteki jest sporządzanie i wydawanie produktów leczniczych, naruszenie warunków koncesji stanowi naruszenie zasad obrotu produktem leczniczym w rozumieniu art. 120 ust. 1 pkt 2 u.p.f. $Z$ tego względu inspekcja farmaceutyczna powinna mieć możliwość władczego wpływu na każdy aspekt prowa-

36 M. Ożóg, System handlu produktem leczniczym i produktami pokrewnymi. Problematyka prawna, Warszawa 2010, s. 364 wraz z powołanym tam orzecznictwem i bibliografią.

37 W. JAKImowicz, Wykładnia w prawie administracyjnym, Kraków 2006, s. 69.

38 L. MorawsKi, Wykładnia w orzecznictwie sądów..., s. 197. 
dzenia działalności gospodarczej w formie apteki, a nakazanie usunięcia ciśnieniomierza $\mathrm{z}$ apteki jest wyłącznie przywróceniem stanu wcześniejszego i usunięciem nieprawidłowości.

\section{Podsumowanie I WNIOSKI}

W sytuacji zaostrzającej się konkurencji na rynku aptecznym coraz większym problemem jest brak jasnego sprecyzowania usług możliwych do świadczenia w aptece. Prowadzi to nieraz do absurdalnych sytuacji, w których inspekcje farmaceutyczne w różnych województwach, na podstawie tych samych przepisów wyciągają różne wnioski, co prowadzi do niejednolitego stosowania przez nie prawa ${ }^{39}$. Co więcej, odnosząc się do komentowanej tu kwestii, problem mierzenia ciśnienia tętniczego krwi w aptece pozostawał nierozwiązany również w poprzednim stanie prawnym. Co więcej, NSA orzekł wówczas o niedopuszczalności takich działań ${ }^{40}$.

O ile należy dopuścić generalną możliwość wyposażenia w ogólnodostępny ciśnieniomierz, to należy uznać za wysoce wątpliwą możliwość dokonywania pomiarów ciśnienia tętniczego w aptece $\mathrm{w}$ obecnym stanie prawnym. Jednym wyjściem z tej sytuacji wydaje się być wydanie rozporządzenia przez ministra właściwego do spraw zdrowia. Konieczne wydaje się w związku z tym wysunięcie postulatu de lege ferenda, do uzupełnienia delegacji art. 86 ust. 9 u.p.f. o wytyczne co do treści aktu. Wynika to wprost z art. 92 Konstytucji. Warto również rozważyć zmianę delegacji fakultatywnej na obligatoryjną, gdyż nałożenie na ministra właściwego do spraw zdrowa obowiązku uregulowania zakresu usług dozwolonych do świadczenia w aptece zapobiegnie $\mathrm{w}$ przyszłości niejasnościom interpretacyjnym, a także pozytywnie wpłynie na działalność aptek i poczucie bezpieczeństwa prowadzenia przedsiębiorstwa.

Należy jednak z całą pewnością odrzucić tezę, jakoby samo uregulowanie usług świadczonych $\mathrm{w}$ aptece $\mathrm{w}$ drodze powszechnie obo-

39 J. Grzelak-Hodor, U. Ludwiczak, M. Markiewicz, Dodatkowe ustugi w aptece: za i przeciw, «Puls Medycyny» 15.2/2008.

40 P. Burakiewicz, Czy w aptece można wykonywać... 
wiązującego aktu wykonawczego do ustawy stanowiło naruszenie art. 22 Konstytucji. Jak zostało wykazane, jest to dopuszczalne zarówno przez doktrynę, jak i w szczególności przez Trybunał Konstytucyjny. Można ew. rozważyć zmianę brzmienia delegacji z art. 86 ust. 9 u.p.f. i jej doprecyzowanie, co zapobiegnie ew. posądzeniom o niekonstytucyjność przyjętego przez ustawodawcę rozwiązania ${ }^{41}$.

Rozpatrując zakres usług dopuszczalnych do świadczenia w aptece, należy uwzględniać zarówno uregulowanie prawne aptek, jak i całokształt systemu ochrony zdrowia w Polsce. O ile wprowadzenie opieki farmaceutycznej wiązałoby się głównie z zmianami przepisów dotyczących bezpośrednio aptek, to zbytnie poszerzanie działalności aptek o inne usługi, jak np. pobieranie krwi czy prowadzenie innych badań może stanowić naruszenie już systemu instytucjonalnego ochrony zdrowia.

A Gloss on Verdict II GSK 1365/10 Issued on 11 ${ }^{\mathrm{TH}}$ JANUARY 2012 By the Polish Supreme Administrative Court in Warsaw

\section{Summary}

The verdict in question concerns the possibility of pharmacies providing services which are not specifically defined in the applicable legal regulations, in this case facilities for patients to take their own blood pressure.

The fact that the status of pharmacies in the Polish healthcare system has not been fully defined has given rise to a number of practical problems, one of which is the extent of additional services which may be rendered in pharmacies. One of the controversial issues is the list of such services under Pharmaceutical law, and the viability of pharmaceutical care being rendered on the premises in pharmacies. Pharma-

41 Por. D. Rymarz, F. Rymarz, Czy działalność gospodarcza podlega ograniczeniom $w$ stopniu większym niż prawa $i$ wolności o charakterze osobistym lub politycznym?, «Przegląd Sejmowy» 5/2008. 
ceutical care has been described in detail in the professional literature, but it has still not been implemented in Polish law and currently there are no opportunities for its implementation in the pharmacies. Nonetheless sometimes it is invoked for the provision of additional services in pharmacies.

Another controversial point is the possibility for the imposition of restrictions on commercial freedom by sub-statutory means, viz. though an executive ordinance. However, under the jurisdiction of the Polish Constitutional Court and according to the professional literature such practices are admissible under certain conditions, e.g. if the relevant statutory act has laid down specific provisions allowing thereof. 